\title{
Cross-border Supply Chain Changes, Opportunities and Countermeasures
}

\author{
Shihua Zeng ${ }^{1}$ \\ ${ }^{1}$ Guangzhou College of Technology and Business Guangzhou, China
}

\begin{abstract}
This paper compares the changes and development trend of cross-border supply chain in the context of Belt and Road, and proposes a strategy of cross-border supply chain development based on the advantages of platform, technology, market and cluster.
\end{abstract}

\section{Introduction}

"The Silk Road Economic Belt and the 21st-Century Maritime Silk Road" is referred to as "the Belt and Road ", the Belt and Road cooperation initiative has been proposed since 2013, and has received positive responses from countries along the Silk Road due to its historical origin of the ancient Silk Road and the call for peaceful development of building a community of human destiny, and has achieved fruitful results after several years of construction and promotion [1-2]. As of November 2020, China has signed 201 cooperation documents with 138 countries and 31 international organizations to build the Belt and Road; non-financial direct investment in countries along the route reached US\$13.02 billion, up $29.7 \%$ year-on-year. The progress of the Silk Road has also made significant breakthroughs in various aspects, with the China-Europe train growing against the trend, becoming a "lifeline" for the delivery of anti-epidemic medical supplies and an important guarantee for stabilizing the cross-border industrial chain between China and Europe; new breakthroughs have been made in Silk Road construction projects with countries along the route, with the opening of the entire China-Laos Railway, the confirmation of cooperation intentions for the first phase of the China-Thailand Railway, and the opening of the Lahore-Orange Line project in Pakistan. Since the outbreak of the epidemic, China has been actively fulfilling its international obligations, supplying global anti-epidemic materials, sharing its experience and vaccine achievements, and providing a large amount of material and technical assistance to countries along the Silk Road, which has sown the seeds of people-to-people contact for the construction of the Silk Road of peace. It has sown the seeds of people-to-people ties and provided the foundation and platform for the "Belt and Road" layout of cross-border supply chains [3].

\section{The Changing Face of Cross-Border Supply Chains}

Supply chain is defined as the composition of parties that directly or indirectly satisfy customer needs and covers the entire range of functions to satisfy customer needs, including product development, marketing, production operations, logistics, distribution, customer service, etc. Cross-border supply chain can be understood as the process of organizing and realizing the supply chain between two or more countries. The reference to crossborder supply chain is not yet common, and in the context of economic globalization, more references and studies are made to global supply chain and global logistics system to support and promote the development of global supply chain. In today's situation of increasing trade frictions and the development of counter-globalization in some countries, the localization of supply chains and the selection of near-shore countries to arrange supply chains will be strengthened, bilateral trade and multilateral trade may replace globalization as the mainstream, and the study of cross-border supply chains may become the focus of research on global economic development [4].

Cross-border supply chain is gradually developed along with the international division of labor. Since China joined WTO in 2001, it has been actively integrated into the global supply chain, and the depth and breadth of cross-border supply chain cooperation has been increasing. It has become another global supply chain center after the United States and Germany, and has become the country with the most complete industrial system in the world. The China-centered supply chain system will undergo profound adjustment under the multiple influences of Belt and Road construction, Sino-US trade friction and epidemic [5].

The Belt and Road is a national-level top-level cooperation initiative proposed by China, relying on the established bilateral and multilateral mechanisms between China and the countries concerned, and actively developing economic partnerships with countries along 
the route with the help of established and proven regional cooperation platforms, which will have a significant impact on the existing cross-border supply chain structure by reducing costs and increasing efficiency, trade circulation and optimizing the division of labor. After 2017 , the initial results of the construction of the Silk Road have appeared, and if the impact of the epidemic in 2020 is excluded, the import and export trade of the Maritime Silk Road has been on the rise for four consecutive years (as shown in Figure. 1), which means that the construction of the Silk Road has been effective in promoting import and export. Export Index, Export Manager Index, and New export order index are all on the rise, and Comprehensive Cost Index of Export Enterprises is on the decline, which means that the construction of Silk Road has effectively reduced the The trend is that the construction of Silk Road has effectively reduced the cost of commodity distribution in the countries along the route (as shown in Figure. 2).

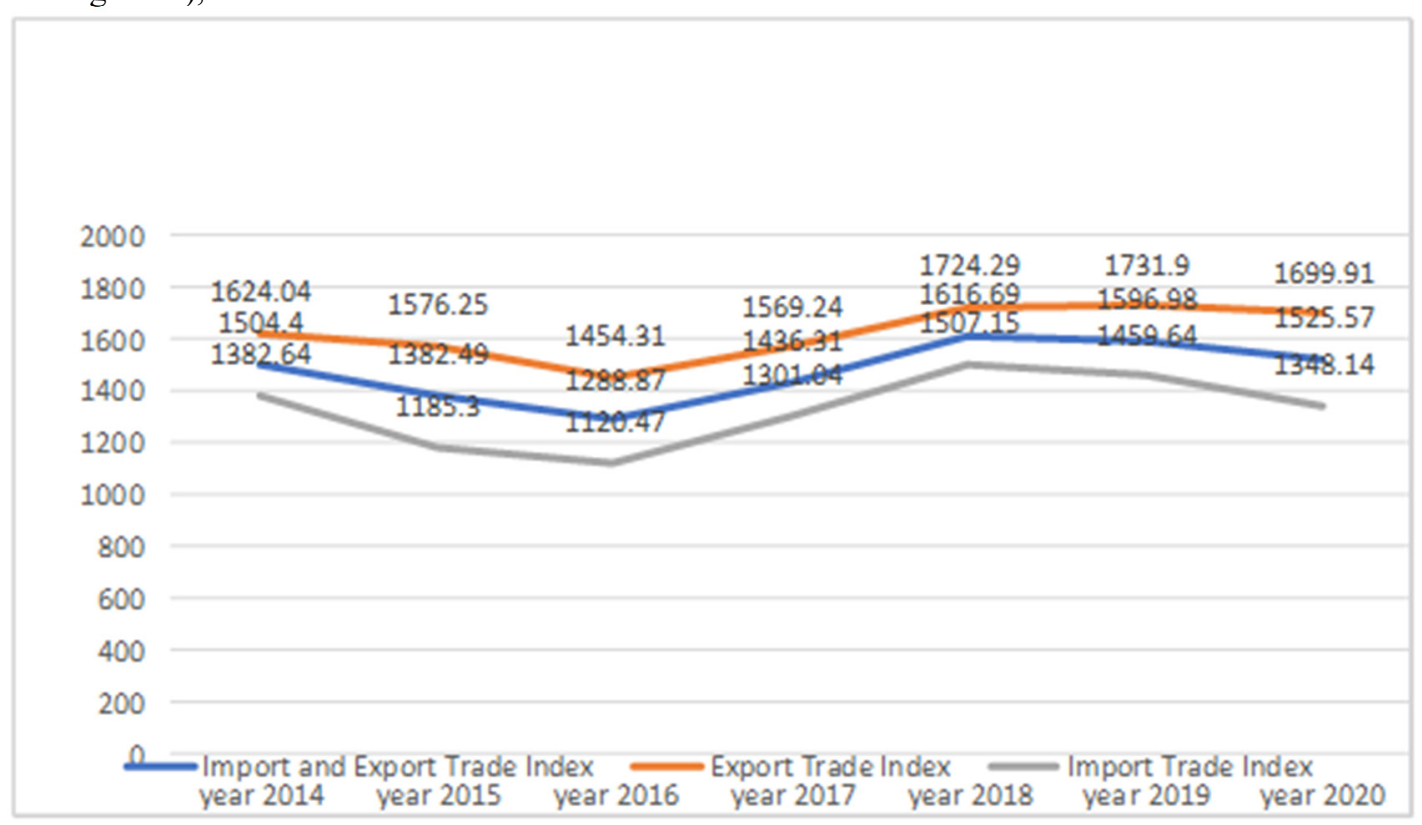

Fig1. Maritime Silk Road Trade Data

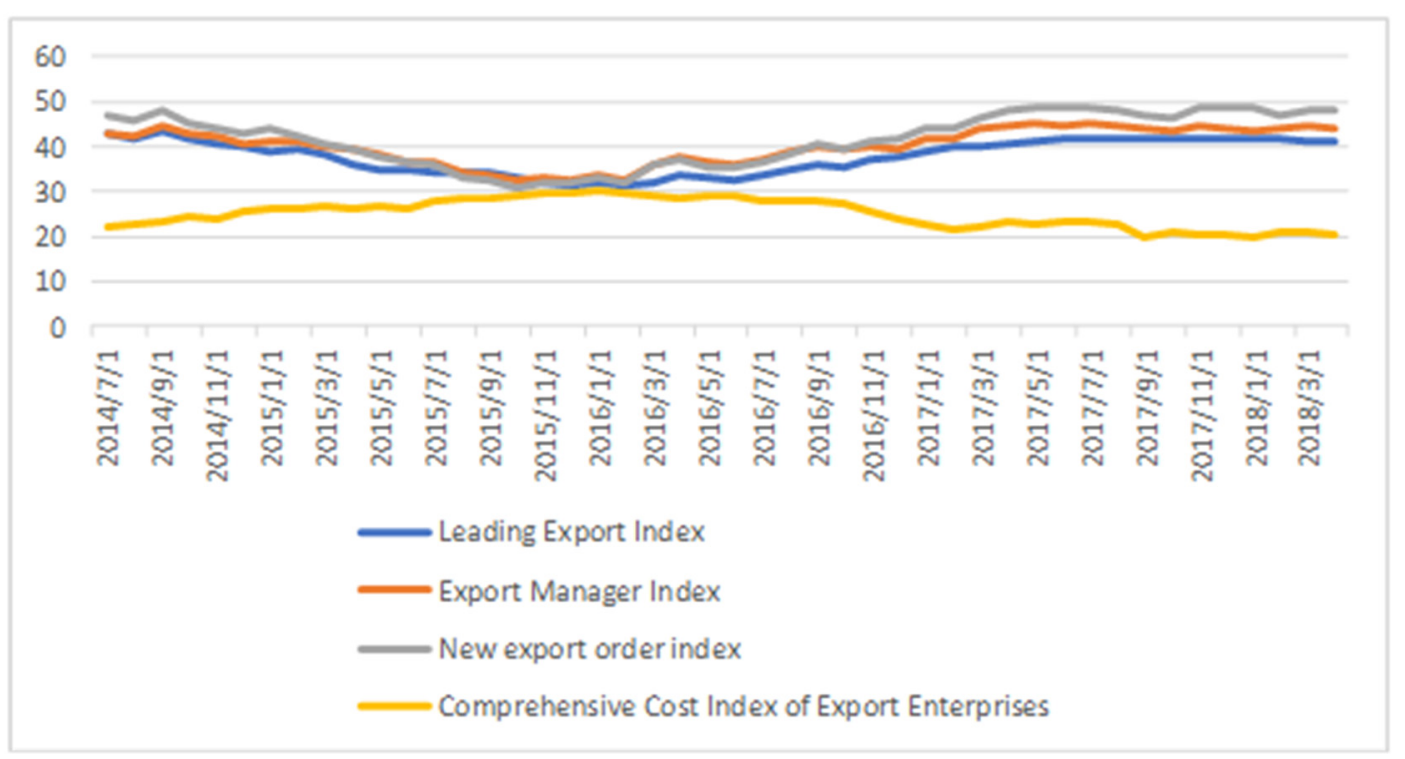

Fig2. Leading Export Index

China-US trade friction and the epidemic have a more profound impact on cross-border supply chains. Countries have realized that supply chains that are related to basic livelihood, industrial security and national security are completely dependent on overseas or concentrated in a certain region, which will put their countries in a passive position when facing disasters or international competition, and diversified supply chains have become the choice of many countries [6].

The cross-border supply chain in the context of Belt and Road shows the following development changes:

The production chain shows the trend of diversification, flattening and near-shore procurement. When formulating industrial policies, the state will give more consideration to industrial diversification, and multinational companies will give more consideration to 
diversified procurement supply and "near-shore sourcing" when building supply chains. Low-cost industries and low-tech industries are more likely to diversify: more than $85 \%$ of companies in the textile and promotional products industry plan to increase suppliers and make the supply chain more resilient to reduce risk. Flatter supply chains can reduce the intermediate stages of supply, lowering the actual cost of product manufacturing and improving product market competitiveness, while flatter supply chains also make it easier for companies to adjust their supply chain strategies to deal with complex international geopolitical changes. In terms of sourcing, China is still considered to be the top three sourcing regions, but the trend of "near-shore sourcing" is increasing in many countries, and near-shore sourcing is to some extent shortening the supply chain.

Logistics links show the trend of internationalization, intelligence and industrial synergy. Internationalization trend: in the context of the Belt and Road construction, infrastructure interconnection between China and the countries along the route is a priority area, jointly planning infrastructure connectivity, jointly promoting the construction of international backbone channels, and gradually connecting the Asian continent and even the Asian, European and African continents. Infrastructure interoperability brings new opportunities for the development of supply chain logistics between China and countries along the route, which not only reduces logistics costs but also increases the opportunities for connectivity and cooperation between national logistics enterprises. The trend of intelligence, a large number of operations and decisions in the process of international supply chain logistics operations, such as inventory system of supply chain and supply chain logistics management, are being solved by popularizing expert systems, artificial intelligence and robotics and other related technologies. As for the trend of industrial synergy, under the background of the Belt and Road construction, crossborder supply chains are becoming more and more closely connected, logistics enterprises are gradually integrated into the competition between supply chains, and information technology connects the whole supply chain enterprises into a network, forming an interlocking whole, and multiple enterprises can realize collaborative operation and coordinated operation under the management of a whole.

The sales chain shows the trend of high efficiency, high response and model innovation. The popularization and application of modern information technology, crossborder e-commerce and other diversified and innovative trade methods have broadened the traditional international trade in the form of business circulation. Compared with traditional international trade, cross-border e-commerce is undoubtedly a more efficient way of international trade, with a shorter transaction chain and faster flow of funds, despite the fact that cross-border e-commerce still needs to be improved in terms of product quality, online payment and customs supervision. At the same time, with the wide application of modern information technology, the sales link of cross-border supply chain responds to consumer demand more quickly and precisely, and judges the market demand more accurately. The wide application of modern information technology not only makes traditional international trade more efficient and diversified, but also the mode of cross-border e-commerce is constantly innovating and developing, such as cross-border ecommerce innovating the original supply chain business model, developing "local sales + overseas warehouses", "overseas direct mail + ", direct brand management, "B2B2C", group purchase type cross-border e-commerce and border warehouse six new cross-border e-commerce business models.

\section{Opportunities of cross-border supply chain in the context of Belt and Road}

\subsection{Policy Dividend Opportunities}

The construction of the Belt and Road clearly defines the positioning of each province in the "Belt and Road" and the key direction of foreign cooperation. Xinjiang is positioned as the core area of the Silk Road Economic Belt, which is a land-based channel to strengthen cooperation with Central Asia, South Asia and West Asia, and an important channel to develop cross-border energy supply and connect to Europe; Fujian is positioned as the core area of the 21st Century Maritime Silk Road, with the advantages of ports, overseas Chinese affairs and sea, and its long-term close cooperation with Southeast Asian countries is the basis for developing cross-border supply chains; Yunnan has the nearest land-based channel to Southeast Asia, and is the base for domestic and foreign enterprises to export to South and Southeast Asia. Yunnan has the closest land access to Southeast Asia, and is the base for domestic and foreign enterprises to export to South and Southeast Asia, and will become the agglomeration area for cross-border industrial development; the three northeastern provinces are important windows for strengthening cross-border trade, technical exchanges and humanities exchanges and cooperation with Russia, South Korea, Mongolia and Japan. Seize the opportunity to make good use of these policies, will have an all-round promotion effect on the regional integrated development and structural optimization of cross-border supply chain.

\subsection{Financing opportunities}

The expected investment in financial cooperation of countries along the Belt and Road is encouraging, policy finance and supporting financial policies will greatly ease the pressure of cross-border supply chain funds, and the Silk Road construction promotes countries along the route to jointly build financing platforms and continuously explore mutually beneficial and win-win investment and financing cooperation models. With the World Bank, the Asian Infrastructure Investment Bank, the Asian Development Bank, the Latin American Development Bank, the European Bank for Reconstruction and Development, the European Investment Bank, the InterAmerican Development Bank, the International Fund for Agricultural Development and other institutions to jointly 
establish a multilateral development and financing cooperation center to promote international financial institutions and related development partners infrastructure interconnection, for the "Belt and Road The "Belt and Road" construction will gather more financial dividends.

\subsection{Facility Connectivity Opportunities}

China actively supports the construction of backbone channels such as highways, railroads, ports, bridges and communication networks in the "Belt and Road" countries, and has basically formed the infrastructure construction pattern of "six corridors and six roads, many ports and many countries". The "Belt and Road" countries on land infrastructure interconnection construction, so that the old Silk Road to give new life, for the provinces and cities along the route, the cross-border supply chain cooperation and trade of countries along the route has brought great opportunities. The Maritime Silk Road, with key ports as nodes, supports the construction of smooth and efficient sea transport corridors and the construction of air hubs, bringing more convenience to cross-border people flow and trade, and creating more opportunities for countries along the sea to integrate into the "Belt and Road".

\subsection{Trade Facilitation Opportunities}

In the "Belt and Road" construction, China promotes the common development of the countries along the route by helping them improve their trade conditions and enhance their trade development capacity. Through policy communication, facility connection, financial integration and people-to-people contact with countries along the route to improve the backward trading conditions of developing countries. Through the modernization of trade flows, the establishment of funds in the World Trade Organization and the World Customs Organization to carry out trade capacity building, support developing economies, especially the least developed countries, to better integrate into the multilateral trading system, and enhance the trade development capacity of developing countries. The improvement of trade facilitation in the "Belt and Road" countries will provide the basis for the "Belt and Road" layout of cross-border supply chains and enhance the competitiveness of countries along the route in the global supply chain layout.

\section{Countermeasures of cross-border supply chain in the context of Belt and Road}

The Belt and Road Initiative is an important platform for China to carry out international development cooperation, and an important strategic opportunity for China to stabilize, upgrade and innovate cross-border supply chains. Relying on the advantages of technology, platform, market and clusters, China will build a cross-border supply chain development strategy of "taking the lead from us and incorporating all", enhance the independent and controllable capability of supply chains, vigorously cultivate the core enterprises of cross-border supply chains of various modes in China, enhance the supply chain awareness of core enterprises, enhance the synergy capability of cross-border supply chains, and build a winwin cross-border supply chain.

\subsection{Build cross-border supply chain core enterprises around China's advantageous industries and empower cross-border supply chain with technology}

For the manufacturer-led supply chain model, China should vigorously develop its advantageous industries in countries along the Belt and Road, emerging advantageous industries such as high-speed rail, Internet, finance, new energy vehicles, etc., and traditional advantageous industries such as nuclear power, textile, steel, coal, metallurgy, etc., and build cross-border supply chain core enterprises around the advantageous industries, and supply chain core enterprises are the key to guarantee the stability of the supply chain. At the same time, it is also necessary to empower the supply chain with technology, use artificial intelligence, block chain, 3D printing, unmanned, Internet of Things and other information technology, promote the standardization process of the supply chain of core enterprises, solve the problem of cross-border supply chain information circulation, crossborder product traceability, and optimize the structure of cross-border supply chain.

\subsection{Build the supply chain of our sales platform as the core business with market advantage}

For the network platform-led E-supply chain model, take full advantage of China's huge market advantage and network sales platform advantage. 2021 China is expected to become the world's largest consumer market, according to the National Bureau of Statistics January 17, 2020 data, 2019 , the total retail sales of social consumer goods 4116.49 billion yuan, a nominal growth of $8.0 \%$ over the previous year, the gap between the scale of consumption between China and the United States from 2017 of $\$ 340$ billion to $\$ 280$ billion in 2018, and further to about $\$ 270$ billion. in 2019, China's consumption scale is equivalent to $95.67 \%$ of the U.S. In 2020 , due to the impact of the epidemic, the U.S. economic growth and consumption setback decline, China still maintains $2.3 \%$ economic growth, becoming the only positive growth of major economies, and in 2021 will is expected to become the world's largest consumer market. In terms of sales platforms, China has the world's largest e-commerce market, and China has produced many excellent ecommerce platforms such as Taobao, Tmall, Jingdong Mall, Suning Tesco, and Vipshop. In the context of the Belt and Road cooperation initiative, domestic crossborder e-commerce enterprises can also form cross-border e-commerce alliances to enhance their bargaining power in cooperation with foreign brands. 


\subsection{Creating cluster supply chain models for free trade zones, free trade ports, and the Greater Bay Area}

The domestic Pearl River Delta, Yangtze River Delta and Bohai Economic Circle have formed many cities and towns with industrial cluster characteristics, and the cluster-type supply chain has a certain development foundation, and more cluster-type supply chains will be formed in the free trade zones and free trade ports to be built in the future. The cluster-type supply chain is formed as a geographically integrated supply chain because of the non-uniqueness of its core enterprises and production homogeneity, and the multiple single-chain nature and production of the supply chain in the region Similarity of supply chains in the region, the enterprises in the region have both single-chain internal collaboration and crosschain collaboration, a kind of network organization of multiple supply chains cross-collaboration, with the support of local government, research institutions, financial institutions, intermediaries and a series of auxiliary institutions to form a synergistic effect and enhance the overall competitiveness of the cluster supply chain. According to the different modes of collaboration, cluster supply chain can be divided into associated cluster supply chain, embedded cluster supply chain, competing cluster supply chain and synergistic cluster supply chain, among which the synergistic cluster supply chain has the most potential because it is most conducive to the longterm development of the supply chain. The construction of cross-border supply chain should build the cluster supply chain model of the free trade zone, free trade port and the Great Bay Area in the context of the Belt and Road.

\section{Conclusion}

This paper analyzes the data of China's cross-border supply chain import and export index, foreign trade export pilot index, comprehensive cost index of export enterprises and export manager index during 2014-2020, and researches the countermeasures of cross-border supply chain development under the background of Belt and Road. Under the background of Belt and Road, China's cross-border supply chain is facing unprecedented opportunities of policy dividend, capital integration, facility connection and trade facilitation, and relying on the advantages of technology, platform, market and clusters, it is important to build a cross-border supply chain development strategy of "we are the main one and we are eclectic" to promote the safe, stable and sustainable development of China's cross-border supply chain. The development of cross-border supply chain is of great significance.

\section{References}

1. W. Qingke, Z. Xiaoli, Z. Zengxiang, W. Chen, Z. Tian and Z. mengdi, "Spatial structures of Chinese Urban Agglomerations in the "Silk Road Economic Belt"," 2018 Fifth International Workshop on Earth Observation and Remote Sensing Applications
(EORSA), Xi'an, China, 2018, pp. 1-5.

2. J. Li and N. Li, "The impact and measures of industrial hollowing-out on China's economic structural adjustments under the new normal," 2016 International Conference on Industrial Economics System and Industrial Security Engineering (IEIS), Sydney, NSW, Australia, 2016, pp. 1-4.

3. J. Lai, "Research on Cross-Border E-Commerce Logistics Supply Under Block Chain," 2019 International Conference on Computer Network, Electronic and Automation (ICCNEA), Xi'an, China, 2019, pp. 214-218.

4. Yan, X. Wang, Y. Zhang and Q. Ding, "Analysis of Cross-Border Supply Chain Network System," 2020 5th International Conference on Electromechanical Control Technology and Transportation (ICECTT), Nanchang, China, 2020, pp. 603-606.

5. H. Jie, L. Enqing and P. Huishu, "Study on performance assess of bonded logistics based on supply chain," 2010 International Conference on Logistics Systems and Intelligent Management (ICLSIM), Harbin, China, 2010, pp. 1300-1304.

6. S. A. McKenna, "Keynote: Global Trade, Borders, and Technology," 2019 Sixth International Conference on eDemocracy \& eGovernment (ICEDEG), Quito, Ecuador, 2019, pp. 14-14. 